\title{
EXPLORATION OF LATENT BARRIERS INHIBITING PROJECT MANAGEMENT PROCESSES IN ADOPTING SMART BUILDING TECHNOLOGIES (SBTS) IN THE DEVELOPING COUNTRIES
}

\begin{abstract}
Purpose: Whilst smart building technologies (SBTs) implementation ensures sustainability, their adoption is hampered by latent barriers, especially in project management processes. These latent barriers must be addressed in order to facilitate the successful and widespread adoption of SBTs. This study explores the significant latent barriers inhibiting the project management processes in adopting SBTs in developing countries.
\end{abstract}

Methodology: A positivist research philosophy couched within a deductive approach was adopted to undertake a quantitative questionnaire survey of 227 project management and design team participants. Descriptive and inferential analytical tools (including a one sample T-test and exploratory factor analysis) were then adopted to interpret data collected.

Findings: The results reveal that the "high cost of smart sustainable materials and equipment" is the major significant barrier hindering the adoption of SBTs in developing countries. Latent barriers were: "structure and time-related barriers", "construction-related barriers" and "human, policy and cost-related barriers."

Originality: The study contributes novel insights into the prevailing nascent discourse on SBTs from the perspectives of construction project managers and design teams in developing countries, particularly. Furthermore, this is the first study that ascertains the significant barriers inhibiting project management processes in adopting SBTs in developing countries.

\section{KEYWORDS}

Significant barriers, developing countries, Ghana, project management processes, smart building technologies

\section{INTRODUCTION}

Buildings and energy consumption within them significantly contribute to fossil fuel energy consumption and concomitant global environmental degradation and pollution (Ürge-Vorsatz et al., 2013, 2018; Addy et al., 2017). Consequently, contemporary buildings of the $21^{\text {st }}$ century must display a high degree of environmental performance in terms of minimising their carbon footprint (Martínez-Molina et al., 2016). For example, the Energy Performance of Buildings Directive (EPBD) asserted that newly constructed buildings in the European Union (EU) must 
adopt NetZero Energy Building (NZEB) (European Union, 2014), as an integral part of smart building (Karlessi et al., 2017). Project managers are at the forefront of attempts to implement energy efficiency to ensure high performance 'greener' buildings. Baleta et al. (2019) posited that integration of a smart building concept based upon multidisciplinary knowledge helps minimize a building's negative environmental impact. Moreover, Ilankoon et al. (2018) and Nižetić et al. (2019) stress the need for smart and efficient management to curb the ripple effects that cause serious issues for building performance and sustainability.

Implementing the smart building concept within a sustainable construction industry, requires a deliberately targeted and managed process to improve the capacity and effectiveness of 'upstream' professional stakeholders who supply built environment products (i.e. infrastructure, industrial premises and residential property) and 'downstream' clients who provide demand for such products. Operations within this supply-demand loop must aspire to meet national policies for products that support sustained national economic and social development objectives (Ofori, 2015). In developing countries such as Ghana research undertaken in the area of sustainable development includes: Sarfo (2016) who developed a framework for enabling contractors to build environmentally sustainable construction processes adaptation capability; Addy et al. (2017) who developed a building energy efficiency assessment tool for assessing the energy efficiency of offices; Gyamfi et al. (2018) who also explored energy efficiency; and Chan et al. (2018) who explored the barriers of green building technologies. This prevailing body of knowledge broadly encapsulated sustainability which is an integral part of the smart building concept, yet adoption rates remains low in developing countries. Ahiabor (2019) opined that opportunities to adopt a smart building model in any economy are clear but for many developing world organizations, harnessing it requires a better understanding of smart building technologies (SBTs). SBTs may include: sensor based networks to monitor and control energy or water consumption within the building or safely systems such as fire detection (Li et al., 2019; Pärn et al., 2019); isolated sensors to monitor room usage and control internal ambient conditions (Li et al., 2020); and electronic devices controlled by internet of things (IoT) which link to cloud based servers that can translate big data into insight user knowledge (or building performance) with precision and speed (Ghosh et al., 2020).

Despite a plethora of research in the area of sustainable development (cf. Koranteng, 2010; Koranteng and Mahdavi, 2011), hitherto the barriers restraining project management processes from adopting SBTs have not been considered. Other related research in the area includes: 
Djokoto et al. (2014) who focused on the challenges to sustainable construction in general, and also centred on consultants; Darko et al. (2017a) who focused on the barriers to the adoption of green building technologies; and Ghansah et al. (2020) who reviewed barriers from extant literature but failed to undertake empirical research to ascertain the underlying significant barriers inhibiting the project management processes for SBTs adoption. Set against this prevailing contextual backdrop, this current study aims to ascertain the significant barriers that prohibit project management processes adopting SBTs in developing countries (with Ghana as a case study). Such knowledge accrued acts as a first step towards finding practical measures to overcome them. Concomitant objectives are to: generate wider polemic debate amongst construction stakeholders; and stimulate government policy makers to invest in positive sustainable interventions in developing countries. Consequently, this study contributes to the ensuing academic discourse on the smart building concept and how such can mitigate environmental degradation.

\section{PROJECT MANAGEMENT PROCESSES FOR THE ADOPTION OF SBTS}

According to the Association for Project Management (2019), project management is the application of processes, methods, skills, knowledge and experience to achieve specific project objectives. Project management comprises of a set of tools which help fulfil the requirement of a system such as waste management, material management and site management $\mathrm{Wu}$ and Low, 2010). Whilst sustainability in project management has been explored extensively, scant research has been conducted to find modernity in the ways for assessing and applying sustainable project management processes when adopting SBTs for smart building projects (Chawla et al., 2018). Project management is an integrative endeavour, i.e. an action, or failure to take action in one area will usually affect other areas. These interactions may be well-understood, or they may be subtle and uncertain. For instance, scope change affects project cost but it may, or may not affect team morale or product quality. This then affects the adoption of SBTs as it changes the scope of construction from the conventional or traditional method of construction. According to the PMBOK 6 (cf. Project Management Institute, 2013), project management processes are concerned with describing and organizing project work such as smart building projects. Project management processes describe a generalized view of how the various project management process commonly interact. It is then imperative to establish the significant challenges capable of restraining the project management processes for adopting SBTs in the developing countries, particularly Ghana. 


\section{Unravelling the Potential Barriers}

Organizations and researchers have become increasingly concerned with sustainability as a project goal and as a characteristic of the processes through which the project is managed. Kivilä et al. (2017) opined that to create a sustainable project, a holistic view to project control is necessary. Therefore, the push and pull factors of project management processes that can help in the successful adoption of SBTs must be considered.

To better understand SBTs adoption and its implementation, the industry's willingness to innovate, and its awareness and appreciation of the barriers to be overcome in relation to the project management processes must be recognised (Mahbub, 2008). Mahbub (ibid) asserted that there is a lack of standard design elements which stimulate the use of automated smart technologies; this is because, repetition elements lead to greater utilisation of these technologies. Hwang and Tan (2012) also discovered challenges to SBTs adoption such as: increases in project cost; high implementation cost of smart construction practices; lack of credible research on palpable benefits of SBTs; and lack of client interest. Numerous literature reviews have identified the barriers restraining project management processes in adopting SBTs in the construction industry - such barriers provide potential variables for this study. Aktas and Ozorhon (2015) proffer that a better understanding of the obstacles to SBTs adoption in specific countries is important because different laws and requirements exist in different countries. Such observations justify this research which focuses on a case study of Ghana. Table 1 represents a bibliometric analysis of the potential barriers inhibiting project management processes for SBTs adoption.

\section{<Insert Table 1 about here>}

\section{METHODOLOGICAL SETTING}

This research adopted a positivist research philosophy contextualised within a deductive approach that sought to test variables identified from extant literature (cf. Table 1). This empirical approach is well founded within contemporary construction and civil engineering management literature. For example: Olanrewaju et al., (2020) recently developed a mathematical based methodology for predicting on-site emissions during ready mixed concrete (RMC) delivery; Aghimien et al. (2020) used fuzzy logic to evaluate the challenges of smart city development in developing countries; and Edwards et al. (2020) used probability models to estimate the likelihood of an operator exceeding exposure to hand-arm vibration from power tools. This body of literature justifies the approach adopted within this current research study. 
For methods employed, extant literature provided survey questions presented within a questionnaire survey data collections instrument (cf. Owusu-Manu et al., 2019). Exploratory factor analysis was then conducted to draw inference from the data and provide discussion on emergent thematic groupings of components and further discussion of these (c.f. Ogunsanya et al., 2019). To develop the data collection instrument, a three stage 'waterfall' approach strategy was adopted to iteratively ad robustly test its validity.

\section{Stage One: Identifying Potential Barriers}

A comprehensive systematic literature review was conducted with the help of Scopus search engine using suitable words such as "barriers to smart buildings", "complex technologies in construction", "sustainable technologies in construction", "smart building", "smart building technologies", "barriers to project management processes" and "sustainable building". After filtering, 56 articles were selected to be relevant and valid for further analysis. The 56 selected relevant articles were approved because Darko and Chan (2017) conducted a systematic review on 36 relevant articles on barriers to the green building adoption. To avoid publication bias, all publications were considered because the concept of smart building remains inchoate and has not yet achieved wider coverage. The list of potential barriers was compiled and presented in a table form (viz: Table 1).

\section{Stage Two: Adequacy and Clarity of the Potential Barriers and Data Collection}

The list of potential barriers was presented to 7 construction industry experts during a pilot survey for validation and clarity. These experts included 1 construction manager, 1 quantity surveyor, 1 architect and 3 research assistants with a minimum of 5 years of experience working in the Ghanaian construction industry (as entry criteria). The barriers were then validated to be the potential barriers of project management processes of adopting SBTs in developing countries, and also seen to align to serve as barriers to the theory of Technology Acceptance Modelling (TAM), underpinning the study. In order to check for the significance, the potential barriers were then presented to be assessed by the targeted respondents via questionnaire survey, using the Likert scale: 1 = Not Significant; 2 = Less Significant; 3 = Moderate; 4 = Significant; 5 = Very Significant. Before checking the significance, the study determined the level of knowledge of the targeted respondents on the barriers hindering the project management processes for SBTs adoption using the scale: 1 = Very Low; 2 = Low; 3 = Moderate; $4=$ High; and $5=$ Very High . 
Due to the unknown number of project managers and construction design teams in the population of 221 construction firms in Ghana, the study adopted the Cochran Formula to determine sample size for the main survey (Cochran, 1963):

$$
n_{0}=\frac{z^{2} \times p(1-p)}{e^{2}}, n_{0}=\frac{(1.96)^{2} \times 0.5(1-0.5)}{(0.05)^{2}}=384.16
$$

$\mathbf{n}_{\mathbf{o}}=$ sample size, which needs to be estimated, $\mathbf{z}=$ selected critical value of desired level of confidence or risk; $95 \%$ confidence level (the value of $(1-\alpha)$ in standard normal distribution $\mathrm{z}$ table, which is 1.96 for $95 \%), \mathbf{p}=$ estimated proportion of an attribute that is present in the population or maximum variability of the population; $50 \%$ variability of the population (which is maximum), $\mathbf{e}=$ desired level of precision or margin of error; and 5\% margin of error. A total of 385 questionnaires were administered to the project managers and construction design teams in the construction industry of Ghana. Purposive sampling and convenient sampling were used because of: 1) the specific characteristics and knowledge of the respondents; and 2) this approach ensured that completed questionnaires could be retrieved without incurred exorbitant costs. Upon retrieval of questions, the study attained a response rate of $58.96 \%$, which is equivalent to 227 responded questionnaires out of 385. The response rate was accepted because Goyder (1985) stated in Mellahi and Harris (2016) state that it is appropriate to adopt response rates between $50 \%$ and $70 \%$.

\section{Stage Three: Reliability of Scale and Data Analysis}

A Cronbach's alpha of 0.7 or greater is encouraged to approve for further analysis (Norušis, 2011), as adopted for this study. The Cronbach's alpha obtained was 0.965 and therefore, further analysis can be undertaken. Frequency was adopted to determine the level of knowledge of the targeted respondents on the barriers of project management processes on the adoption of SBTs. After which a mean score was used to determine the central trend of the potential barriers based on data collected. A one sample T-test was then used to test the significant influence of the potential barriers inhibiting project management processes of the SBTs adoption. Due to the numerous natures of potential barriers, the study further adopted exploratory factor analysis to uncover the principal barriers from the set of 26 potential barriers restraining the project management processes for SBTs adoption (Thompson, 2007). 


\section{LEVEL OF KNOWLEDGE ON THE BARRIERS INHIBITING PROJECT MANAGEMENT PROCESSES ON THE ADOPTION OF SBTS}

Figure 1 indicates the frequency of responses showing the level of knowledge of the barriers hindering the project management processes for SBTs adoption. The results depict that the majority of survey respondents have a moderate level of knowledge on the barriers to the adoption of SBTs in Ghana, followed by 94 respondents having a high level of knowledge. This result is considered to be valid since the respondents are well endowed with the constraints in regards to the project management processes on adopting and implementing SBTs (cf. Djokoto et al., 2014; Darko et al., 2017a).

\section{<Insert Figure 1 about here>}

\section{Influence of the Barriers of Project Management Processes on the Adoption of SBTs}

Table 2 reveals that the major barrier is the "High cost in smart sustainable material and equipment" with the highest mean value of 4.14 , which is $>$ the hypothetical mean value of four ( 4 = significant). This result is consistent with Chan et al. (2016) who discovered that "higher cost of technologies" was the main barrier underlying the project management processes to adopt new innovations in the construction industry. Ahn et al. (2013) pronounced higher cost of technology product as part of the key barriers to adopt technology in the construction industry. The study's finding also contributes to the fact that "high cost of material and technologies" is capable of restricting the project managers and the construction teams from adopting SBTs in Ghana.

\section{<Insert Table 2 about here>}

The one sample T-test results revealed that almost all of the identified factors or variables were significant barriers restraining the project management processes in adopting SBTs ( $\mathrm{p}$-value < 0.05), except "planning of different construction techniques" ( $\mathrm{p}=0.056)$, "specific budget specification of the smart sustainable building project" $(\mathrm{p}=0.462)$, "availability of smart sustainable material and equipment" ( $\mathrm{p}=0.348)$, "resistance to change from traditional practices" ( $\mathrm{p}=0.112)$, "technical difficulties during construction processes or lack of the technical skills regarding smart technologies and techniques" $(\mathrm{p}=0.727)$ and "unfamiliarity with smart building technology(SBT)/worker's unaware of the correct methods and procedures" $(\mathrm{p}=0.875)$, which had $\mathrm{p}$-value $>0.05$. 


\section{EXPLORATORY FACTOR ANALYSIS}

Adopting factor analysis requires that the strength of the relationship among the variables is checked. Antwi-Afari (2016) posited that the suitability of adopting factor analysis requires the number of variables to be in a range of 20 to 50. The study adheres to this requirement, as the number of identified barriers were 26. Bartlett's test of sphericity and Kaiser-Meyer-Olkin (KMO) measure of sampling adequacy were the two statistical measures adopted in assessing the factorability of the collected data. Tabachnick and Fidell (2001) explained that Bartlett's test of sphericity is deemed acceptable for factor analysis if it is significant $(\mathrm{p}<0.05)$ and KMO falls within 0 to 1 ; where 0.6 is proposed to be minimum value for an acceptable factor analysis. Results indicate that the KMO value was 0.943 which is confirms sampling accuracy of the study (Hair et al., 2010) whilst Bartlett's test of sphericity produced an approximation of $x 2=4813.605$ $(\mathrm{p}<0.05)$. This then implies that the data can be analysed using factor analysis.

Communality is a squared variance-accounted-for statistics reflecting how much variance in measured variables is reproduced by the model's latent construct (Field, 2000). Communality is conceptualized as how much of the variance of a measured/observed variable is useful in delineating the model's latent variables. According to Field (2000), if the extraction for the communality is $>0.50$, the extracted factors account for a large proportion of the variable variance and is reflected well via the extracted factors. Hence, the factors analysis is reliable, as indicated by Table 3. When not high, the sample size has to compensate for that. From Table 4, the result depicts that the study's identified variables all had an extraction value $>0.50$, therefore, the factor analysis results are reliable.

\section{<Insert Tables 3 about here>}

From Table 4, only the first three components recorded an eigenvalue of $>1(13.883,1.808$, and 1.274), based on a rule that the number of factors to rotate in the eigenvalues must be $>1$ (Cardoso and Cruz-Almeida, 2016). Each of the three components obtained percentage of variance as indicated on Table 4; component 1 obtained the highest variance of $53.395 \%$, component 2 accounted for a variance of $6.953 \%$ and lastly, component 3 obtained a variance of 4.900 , being the third. The three components cumulatively obtained a total variance of $65.247 \%$ which is consistent with the requirement affirmed by Field (2005) that is, the extracted components should together explain at lease a variance of 50\%. Figure 2 depicts the Scree test 
used to determine the retainment of the factors in carrying out factor analysis. This is created by plotting each of the factors' eigenvalues and inspecting the plot to find a point at which the shape of the curve changes direction and becomes horizontal. According to Cattell (1966), it is recommended that all the factors above the elbow be retained, as these factors contribute most to the explanation of the dataset variance. Figure 2 illustrates that the first three components are recommended for this study.

Table 5 introduces the rotational components matrix, where successful extracted components of the number of factors is interpreted. Norušis (2011) asserted that, to achieve this process, the factors are rotated to aid and improve the interpretability of the result in factor analysis. The study adopted the varimax method of orthogonal rotation, which attempts to minimise the number of variables that have high loadings on each factor (Pallant, 2005).

\section{<Insert Tables 4, Table 5 and Figure 2 about here>}

The reliability of the three components were then measured by running Cronbach's Alpha. According to Santos (1999), Cronbach's Alpha coefficient checks the reliability and consistency, ranging from 0 to 1 ; where 1 is the highest level of validity and reliability of quantitative inputs. Norušis (2011) asserted the threshold for Cronbach's Alpha to be 0.7, after which the component can be reliable. The result indicated that the Cronbach's Alpha for each of the component was > 0.7, i.e. component 1 (0.941), component 2 (0.914) and component 3 (0.909). Therefore, the three components are reliable.

\section{DISCUSSION}

The result indicated that "high cost in smart sustainable material and equipment" was the major barrier to the adoption of SBTs in the developing country of Ghana. The result is consistent with Chan et al. (2016) and Ahn et al. (2013), who proffer that high cost is a major constraint to adopting new technologies in the construction industry. To determine the significance of the barriers, the study's results revealed that almost all the identified potential barriers are statistically significant in restricting the adoption of SBTs except: "planning of different construction techniques", "specific budget specification of the smart sustainable building project", "availability of smart sustainable material and equipment", "resistance to change from traditional practices", "technical Difficulties during construction processes or lack of the technical skills regarding smart technologies and techniques" and "unfamiliarity with SBT /worker's unaware of the correct methods and procedures". With some of the barriers being 
statistically insignificant, the study adopted exploratory factor analysis where the 26 barriers were categorized into three (3) principal factors, namely: component 1 (structure and timerelated barriers); component 2 (construction-related barriers); and component 3 (human, policy and cost-related barriers) - refer to Table 6.

\section{<Insert Table 6 about here>}

\section{Component 1: Structure and Time-Related Barriers}

The underlying component accounts for $53.395 \%$ of the total variance and consists of twelve barriers namely: 1) "required date of completion"; 2) "specific budget specification of the smart sustainable building project"; 3) "more alteration and variation with the design during the construction processes"; 4) "unforeseen circumstances in smart building project"; 5) "smart building consultant delay in provident information"; 6) "conflict of interest between consultant and project manager"; 7) "structure and organization of the construction industry"; 8) "difficulty in approving payment disbursement to suppliers and subcontractors"; 9) "special request from client pertaining to specific SBTs to be used"; 10) "lack of communication and interest among project team members"; 11) "level of risk the client is willing to take in SBTs"; and 12) "more time is required to implement smart construction practices onsite." These factors encapsulate the structure and time-related barriers within an organization. The result indicated that "required date of completion" had the highest factor loading of 0.731 and was the most critical barrier to SBTs adoption within this component. Hwang and Ng (2012) and Kerzner (2017) also labelled time for completion of smart buildings as a major barrier due to difficulty in procuring smart technologies. "Specific budget specification of the smart sustainable building project" is regarded as the factor with the second highest loading but the one sample T-test revealed this factor as being statistically insignificant. Table 6 illustrates that project managers and the construction design teams adhere to the fact that all the 12 factors are qualified to be under component one (1), therefore, have significant influence except "specific budget specification of the smart sustainable building project" (p-value greater than 0.05). This study has clearly identified the barriers inhibiting the project management processes in adopting SBTs in developing countries thereby, revealing structure and time-related barriers as principal barriers.

\section{Component 2: Construction-Related Barriers}

The underlying component explains $6.953 \%$ of the total variance and comprises of eight critical barriers viz.: 1) "adoption of different contract forms of project delivery"; 2) "the design, orientation and structure of the building"; 3) "lengthy approval for new technologies within the 
organization": 4) "planning of different construction sequences"; 5) "planning of different construction techniques"; 6) "longer time required during the pre-construction processes"; 7) "difficulty in comprehending the sustainable specifications in the contract details"; 8) "difficulty in the selection of subcontractors in providing smart sustainable construction services." All barriers significantly influence the adoption of SBTs, except "planning of different construction techniques" - a one sample T-test declared this factor as being statistically insignificant ( $\mathrm{p}>$ 0.05). The present study revealed the barrier variables under the construction-related factors capable of constraining the project management processes in adopting SBTs in developing countries. Also, "adoption of different contract forms of project delivery" which had the highest factor loading of 0.799 was the most critical barrier among the construction-related barriers. This study has therefore revealed construction-related barriers as a principal barrier limiting the project management processes in adopting SBTs in the construction industry.

\section{Component 3: Human, Policy and Cost-Related Barriers}

Like component 3, this underlying component also comprises six barriers, namely: 1) "unfamiliarity with SBT/worker's unaware of the correct methods and procedures"; 2) "technical difficulties during construction processes or Lack of the technical skills regarding smart technologies and techniques"; 3) "availability of smart sustainable material and equipment"; 4) "resistance to change from traditional practices"; 5) "high cost in smart sustainable materials and equipment"; and 6) "government policy". This component explains $4.900 \%$ of the total variance. The barriers were known to have a significant influence on the adoption of SBTs except: “unfamiliarity with SBT/worker's unaware of the correct methods and procedures"; "technical difficulties during construction processes or lack of the technical skills regarding smart technologies and techniques"; "availability of smart sustainable material and equipment"; and "resistance to change from traditional practices." These factors were statistically insignificant on restraining the project management processes in adopting SBTs based on the result from one sample T-test ( $\mathrm{p}>0.05)$. The study also declares "high cost in smart sustainable materials and equipment" and "government policy" as being significant barriers. The study revealed that "unfamiliarity with SBT /worker's unaware of the correct methods and procedures" was the most critical barrier among the human, policy and cost-related barriers with the highest factor loading of 0.828 but has insignificant influence. "High cost in smart sustainable materials and equipment" was finally decided on because it was found to be a significant barrier with highest factor loading of 0.713 . This finding is consistent with the result of the mean score analysis where "high cost in smart sustainable materials and equipment" was 
chosen as the major barrier restraining the project management processes. The study has again revealed human, policy and cost-related barriers as principal barrier to the project management processes in adopting SBTs in developing countries.

In summary, the analysis discovered that 20 out of 26 barriers were significant in influencing the adoption of SBTs in developing countries such as Ghana. Furthermore, the "high cost in smart sustainable materials and equipment" was regarded as the major barrier. Exploratory factor analysis was adopted to reveal the underlying barriers to the SBTs adoption including "structure and time-related barriers", "construction-related barriers" and "human, policy and cost-related barriers." The results also portrayed that the most dominant of the three components was "structure and time-related barriers", thus, indicating that there is the need to consider the structure of an organization and the project timing when adopting SBTs. The study's findings not only contributed to filling the prevailing knowledge gap concerning the adoption of SBTs in developing countries, but also offer an valuable reference for helping policy makers and practitioners take suitable measures to help alleviate the barriers. This study may also be useful for international organizations and advocates interested in promoting the SBTs adoption in developing countries to mainly achieve sustainability. Although the research was conducted in the West African country of Ghana, the findings may also resonate and be useful to other developing countries around the world. This then implies that, using the proposed barriers restraining the project management processes towards the SBTs adoption, similar studies could be performed in different developing countries. Such work could observe social, economic and/or political differences which could help in bringing specific solutions to dealing with the specific barriers reported upon or add or remove barriers within various geo-political contexts.

\section{CONCLUSION}

This study revealed significant barriers hindering the project management process in adopting SBTs in developing countries such as Ghana. In meeting the aim, 26 potential barriers were identified from extant literature. The study set out the dynamics of the barriers inhibiting the project management processes in adopting SBTs from the perspective of project managers and construction design teams. The result portrayed that "high cost in smart sustainable material and equipment" is the major barrier underlying the project management processes to adopt SBTs. Using a one sample T-test, the study also revealed that, the following barriers are statistically insignificant: "planning of different construction techniques", "specific budget specification of the smart sustainable building project", "availability of smart sustainable material and 
equipment", "resistance to change from traditional practices", "technical difficulties during construction processes or lack of the technical skills regarding smart technologies and techniques" and "unfamiliarity with SBT/Worker's unaware of the correct methods and procedures." The use of exploratory factor analysis, discovered the underlying principal barriers of project management processes in adopting SBTs to be "structure and time-related barriers", "construction-related barriers" and "human, policy and cost-related barriers." With originality, the study has presented the principal and significant barriers restraining the project management processes in adopting SBTs in developing countries, and contributed to the emerging discussions on SBTs in developing countries from perspectives of project managers and construction design teams.

In general, predicting barriers in advance and trying to avoid them is decisive to avoid unexpected losses of project resources. Practically, the study's outcome provides policy makers, stakeholders, project managers and practitioners in the construction industry an insight into the significant latent barriers that inhibit the project management processes in adopting SBTs in developing countries, specifically Ghana. In practice, the study proposes contributively that the barriers must be made known to help achieve successful and effective SBTs adoption in Ghana. The study's result can be incorporated into policy making in relation to achieving sustainability in the construction industry by considering the significant/latent barriers during decision making. Additionally, this study can serve as a guide for stakeholders that decide to adopt SBTs, so that they can handle the difficulties faced during the process with greater ease, casting a light on the barriers and proposing optimal solutions and guidelines for overcoming them. Since "high cost of sustainable materials and equipment" is a major barrier underpinning the project management processes in adopting SBTs, the study recommends policy makers to pass policies that will lead to affordability of sustainable materials and equipment which can enhance SBTs adoption. The study's outcome should aid policy-makers to better understand and prioritize barriers to develop effective action and policy interventions towards successful adoption of SBTs in developing countries. Albeit seeking consent from the experts in the construction industry in Ghana, which may serve as a limitation of the study; the research focused on the quality of the responses rather than the quantity. The selected experts, being project managers and construction design teams, were deemed knowledgeable in responding to the questionnaires. Also, only 26 potential barriers were carefully reviewed, refined and selected to serve as a significant barrier hindering the project management processes in adopting SBTs in developing countries. The study considered Ghana as a case study of the developing countries but the findings provide a lesson and 
extrapolated to other developing countries. Smart building is an emerging area of research in both construction and project management in developing countries, so the study recommends future research in other developing countries, as well as discovering the factors capable of promoting SBTs. 


\section{REFERENCES}

Addy, N. M., Adinyira, E. and Joshua, A., (2017). Developing a Building Energy Efficiency Assessment Tool for Office Buildings in Ghana: Delphic Consultation Approach. Energy Procedia, 111, pp.629-638.

Aghimien, D.O., Aigbavboa, C., Edwards, D.J., Mahamadu, A-M., Olomolaiye, P., Onyia, M., and Nash, H. (2020) A fuzzy synthetic evaluation of the challenges of smart city development in developing countries, Smart and Sustainable Built Environment DOI: https://doi.org/10.1108/SASBE-06-2020-0092

Ahiabor, G., (2019), Smart buildings are coming: But who holds the keys? https://www.graphic.com.gh/news/general-news/smart-buildings-are-coming-but-whoholds-the-keys.html, Accessed: 17/08/2019.

AlSanad, S., (2015). Awareness, drivers, actions, and barriers of sustainable construction in Kuwait. Procedia engineering, 118, pp.969-983.

Association for Project Management, (2019), Project Management, https://www.apm.org.uk/resources/what-is-project-management/, $\quad$ Accessed: 06/09/2019.

Baleta, J., Mikulčić, H., Klemeš, J.J., Urbaniec, K., and Duić, N., (2019). Integration of energy, water and environmental systems for a sustainable development. Journal of Cleaner Production, 215, pp. 1424-1436, https://doi.org/10.1016/j.jclepro.2019.01.035.

Chawla, V., Chanda, A., Angra, S. and Chawla, G., (2018). The sustainable project management: A review and future possibilities. Journal of Project Management, 3(3), pp.157-170.

Djokoto, S., Dadzie, J. and Ohemeng-Ababio, E. (2014). Barriers to sustainable construction in the Ghanaian construction industry: consultants' perspective. Journal of Sustainable Development. 7, pp. 134-143.

Edwards, D.J., Rillie, I., Chileshe, N. Lai, J., Hossieni , M. Reza, and Thwala, W.D. (2020) A field survey of hand-arm vibration exposure in the UK utilities sector, Engineering, Construction and Architectural Management. DOI: https://doi.org/10.1108/ECAM-09$\underline{2019-0518}$

Ghansah, F.A., Owusu-Manu, D.-G. and Ayarkwa, J. (2020), Project management processes in the adoption of smart building technologies: a systematic review of constraints, Smart and Sustainable Built Environment, Vol. ahead-of-print No. ahead-of-print. https://doi.org/10.1108/SASBE-12-2019-0161.

Ghosh, A., Edwards, D.J., Hossieni, M. Reza., Al-Ameri, R., Abewajy, J. and Thwala, W.D. (2020) Real-Time Structural Health Monitoring for Concrete Beams: A Cost-Effective 
'Industry 4.0' Solution Using Piezo Sensors, International Journal of Building Pathology and Adaptation. Vol. ahead-of-print No. ahead-of-print. https://doi.org/10.1108/IJBPA12-2019-0111

Hwang, B.G., Shan, M. and Looi, K.Y., (2018). Key constraints and mitigation strategies for prefabricated prefinished volumetric construction. Journal of cleaner production, 183, pp.183-193.

Kerzner, H., (2017). Project management: a systems approach to planning, scheduling, and controlling. John Wiley \& Sons.

Kivilä, J., Martinsuo, M. and Vuorinen, L., (2017). Sustainable project management through project control in infrastructure projects. International Journal of Project Management, 35(6), pp.1167-1183.

Koranteng, C. and Mahdavi, A., (2011). An investigation into the thermal performance of office buildings in Ghana. Energy and Buildings, 43(2-3), pp.555-563.

Li, H.X., Edwards, D.J., Hosseini, M. Reza., Costin, G.P. (2019) A review on renewable energy transition in Australia: an updated depiction. Journal of Cleaner Production. DOI: https://doi.org/10.1016/j.jclepro.2019.118475

Li, H.X, Zhang, Y., Edwards, D.J. and Hosseini, M. Reza (2020) Improving The Energy Production of Roof-Top Solar PV Systems Through Roof Design, Building Simulation. Vol 13, pp. 475-487. DOI: https://doi.org/10.1007/s12273-019-0585-6

Mohanty, S.P., Choppali, U. and Kougianos, E., (2016). Everything you wanted to know about smart cities: The internet of things is the backbone. IEEE Consumer Electronics Magazine, 5(3), pp.60-70.

Nižetić, S., Djilali, N., Papadopoulos, A. and Rodrigues, J.J., (2019). Smart technologies for promotion of energy efficiency, utilization of sustainable resources and waste management. Journal of Cleaner Production, https://doi:10.1016/j.jclepro.2019.04.397.

Noe, R.A., Hollenbeck, J.R., Gerhart, B. and Wright, P.M., (2017). Human resource management: Gaining a competitive advantage. New York, NY: McGraw-Hill Education.

Norušis, M.J., (2011). IBM SPSS statistics 19 guide to data analysis. Upper Saddle River, New Jersey: Prentice Hall.

Ogunsanya, O.A., Twala, W.D., Aigbavboa, C. and Edwards, D.J. (2019) Barriers to sustainable procurement in the Nigerian construction industry: an exploratory factor analysis, International Journal of Construction Management. DOI: https://doi.org/10.1080/15623599.2019.1658697 
Olanrewaju, O., Chileshe, N. and Edwards, D. J. (2020) Estimating on-site emissions during ready mixed concrete (RMC) delivery: A methodology. Case Studies in Construction Materials. DOI: https://doi.org/10.1016/j.cscm.2020.e00439

Owusu-Manu, D., Asiedu, R., Edwards, D., Donkor-Hyiaman, K., Abuntori, P. and El-Gohary, H. (2019) An assessment of mortgage loan default propensity in Ghana, Journal of Engineering, Design and Technology, 17(5), pp. 985-1017. https://doi.org/10.1108/JEDT-01-2019-0016

Pärn, E.A., Edwards, D., Riaz, Z., Mehmood, F. and Lai, J. (2019) Engineering-out hazards: digitising the management working safety in confined spaces, Facilities, Vol. 37 No. 3/4, pp. 196-215. DOI: https://doi.org/10.1108/F-03-2018-0039

Polat, G., Cetindere, F., Damci, A. and Bingol, B.N., (2016). Smart home subcontractor selection using the integration of ahp and evidential reasoning approaches. Procedia engineering, 164, pp.347-353.

Project Management Institute (2013). A Guide to Project Management Body of Knowledge (PMBOK® Guide), fifth ed. Project Management Institute, Newtown Square, PA USA.

Sarfo, M., (2016), Contractor's adaptation to the environmentally sustainable construction process in Ghana, Department of Construction Technology and Management, Kwame Nkrumah University of Science and Technology, Doctoral Dissertation, http://ir.knust.edu.gh/bitstream/123456789/10456/1/Sarfo_Thesis_final\%20submission. pdf.

Zhang, X., Shen, L., Wu, Y. and Qi, G., (2011). Barriers to implement green strategy in the process of developing real estate projects. The Open Waste Management Journal, 4(1), pp.234-236. 
Table 1 - Bibliometric Analysis of Potential Barriers Inhibiting the Project Management Processes to Adopt SBTs

\begin{tabular}{|c|c|c|}
\hline Code & Barriers & References \\
\hline BF1 & Adoption of different contract forms of project delivery & $\begin{array}{l}\text { Tagaza and Wilson (2004), Rahmani et al. (2013), Hwang } \\
\text { and } \mathrm{Ng} \text { (2012), Olubunmi et al. (2016) }\end{array}$ \\
\hline $\mathrm{BF} 2$ & The design, orientation and structure of the building & Hwang and $\mathrm{Ng}$ (2012), Noe et al. (2017), Das et al. (2017) \\
\hline BF3 & Planning of different construction sequences & $\begin{array}{l}\text { Hwang and } \mathrm{Ng}(2012) \text {, Zhang et al. (2015), Nowotarski and } \\
\text { Paslawski (2015) }\end{array}$ \\
\hline $\mathrm{BF} 4$ & Planning of different construction techniques & Hwang and $\mathrm{Ng}$ (2012), AlSanad (2015), Hwang et al. (2018) \\
\hline BF5 & Lengthy approval for new technologies within the organization & $\begin{array}{l}\text { Eisenberg et al. (2002), Ling (2003), Tagaza and Wilson } \\
\text { (2004), Zhang et al. (2011a), Hwang and Ng (2012), Hwang } \\
\text { and Ng (2013) }\end{array}$ \\
\hline BF6 & Longer time required during the pre-construction processes & $\begin{array}{l}\text { Hwang and } \mathrm{Ng}(2012) \text {, Grover and Froese (2016), Jabar and } \\
\text { Ismail (2018) }\end{array}$ \\
\hline BF7 & $\begin{array}{l}\text { Difficulty in comprehending the sustainable specifications in the } \\
\text { contract details }\end{array}$ & 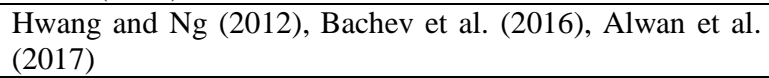 \\
\hline BF8 & $\begin{array}{l}\text { Difficulty in approving payment disbursement to suppliers and } \\
\text { subcontractors }\end{array}$ & Hwang and Ng (2012), Teku (2015), Peters et al. (2019) \\
\hline BF9 & $\begin{array}{l}\text { Difficulty in the selection of subcontractors in providing smart } \\
\text { sustainable construction services }\end{array}$ & Hwang and Ng (2012), Polat et al. (2016), Polat, (2016) \\
\hline BF10 & $\begin{array}{l}\text { More time is required to implement smart construction practices } \\
\text { onsite }\end{array}$ & Hwang and Ng (2012), Tagaza and Wilson (2004) \\
\hline BF11 & $\begin{array}{l}\text { More alteration and variation with the design during the construction } \\
\text { processes }\end{array}$ & Hwang and Ng (2012), Eastman (2018) \\
\hline BF12 & $\begin{array}{l}\text { Specific budget specification of the smart sustainable building } \\
\text { project }\end{array}$ & $\begin{array}{l}\text { Hwang and } \mathrm{Ng} \text { (2012), Mohanty et al. (2016), Cease et al. } \\
\text { (2019) }\end{array}$ \\
\hline BF13 & Required date of completion & Hwang and Ng (2012), Kerzner (2017) \\
\hline BF14 & $\begin{array}{l}\text { Level of risk the client is willing to take in Smart Building } \\
\text { Technologies (SBTs) }\end{array}$ & Hwang and $\mathrm{Ng}$ (2012), Jorisch et al. (2018) \\
\hline BF15 & $\begin{array}{l}\text { Special request from client pertaining to specific Smart Building } \\
\text { Technologies to be used }\end{array}$ & $\begin{array}{l}\text { Hwang and } \mathrm{Ng} \text { (2012), Long et al. (2016), Minoli et al. } \\
\text { (2017) }\end{array}$ \\
\hline BF16 & Lack of communication and interest among project team members & Tagaza and Wilson (2004), Hwang and Ng (2013) \\
\hline BF17 & Smart building consultant delay in provident information & $\begin{array}{l}\text { Hwang and Ng (2012), Nowotarski and Paslawski (2015), } \\
\text { Harris et al. (2018) }\end{array}$ \\
\hline BF18 & Conflict of interest between consultant and project manager & Hwang and $\mathrm{Ng}$ (2012), Meng and Boyd (2017) \\
\hline BF19 & High cost in smart sustainable materials and equipment & $\begin{array}{l}\text { Mahbub (2008), Zhang et al. (2011a, b,c), Hwang and Ng } \\
\text { (2012), Hwang and Tang (2013), Shi et al. (2013), Ahn et al. } \\
\text { (2013), Chan et al. (2016), Darko et al. (2017), Nguyen et al. } \\
\text { (2017), Durdyev et al. (2018) }\end{array}$ \\
\hline BF20 & Availability of smart sustainable material and equipment & $\begin{array}{l}\text { Williams and Dair (2007), Hwang and } \mathrm{Ng} \text { (2013), } \\
\text { Ringenson et al. (2017), Drossel et al. (2018) }\end{array}$ \\
\hline BF21 & Resistance to change from traditional practices & $\begin{array}{l}\text { Shi et al. (2013), Gou et al. (2013) Kasai and Jabbour (2014), } \\
\text { Du et al. (2015), Chan et al. (2016) }\end{array}$ \\
\hline BF22 & $\begin{array}{l}\text { Technical Difficulties during construction processes or Lack of the } \\
\text { technical skills regarding smart technologies and techniques }\end{array}$ & $\begin{array}{l}\text { Brown, 1989, Tagaza and Wilson (2004), Williams and Dair } \\
\text { (2007), Mahbub (2008), Hwang and Tan (2010), Hwang and } \\
\text { Ng (2012), Shi et al. (2013), Gou et al. (2013), Du et al. } \\
\text { (2015), Kasai and Jabbour (2014), Hsu (2016), Rizos et al. } \\
\text { (2016) }\end{array}$ \\
\hline BF23 & $\begin{array}{l}\text { Unfamiliarity with Smart Building Technology /Worker's unaware } \\
\text { of the correct methods and procedures }\end{array}$ & $\begin{array}{l}\text { Pettersen (1999); Ling (2003), Tagaza and Wilson (2004), } \\
\text { Williams and Dair (2007), Mahbu, (2008), Love et al. } \\
\text { (2011), Hwang and Ng (2012), Ahn et al. (2013), AlSanad } \\
\text { (2015), Chan et al. (2016), Darko et al. (2017), Durdyev et } \\
\text { al., 2018) }\end{array}$ \\
\hline BF24 & Government policy & Hwang and $\mathrm{Ng}$ (2012), Shen et al. (2017ab), \\
\hline BF25 & Unforeseen circumstances in smart building project & Hwang and $\mathrm{Ng}$ (2013), Jagarajan et al. (2017) \\
\hline BF26 & Structure and Organization of the Construction Industry & $\begin{array}{l}\text { Mahbub (2008), Samari et al. (2013), Hwang and Ng } \\
\text { (2013), Chan et al. (2016), Shen et al. (2017ab), Chan et al., } \\
\text { 2017, Durdyev et al., 2018 }\end{array}$ \\
\hline
\end{tabular}

Figure 2 - Radar Diagram 


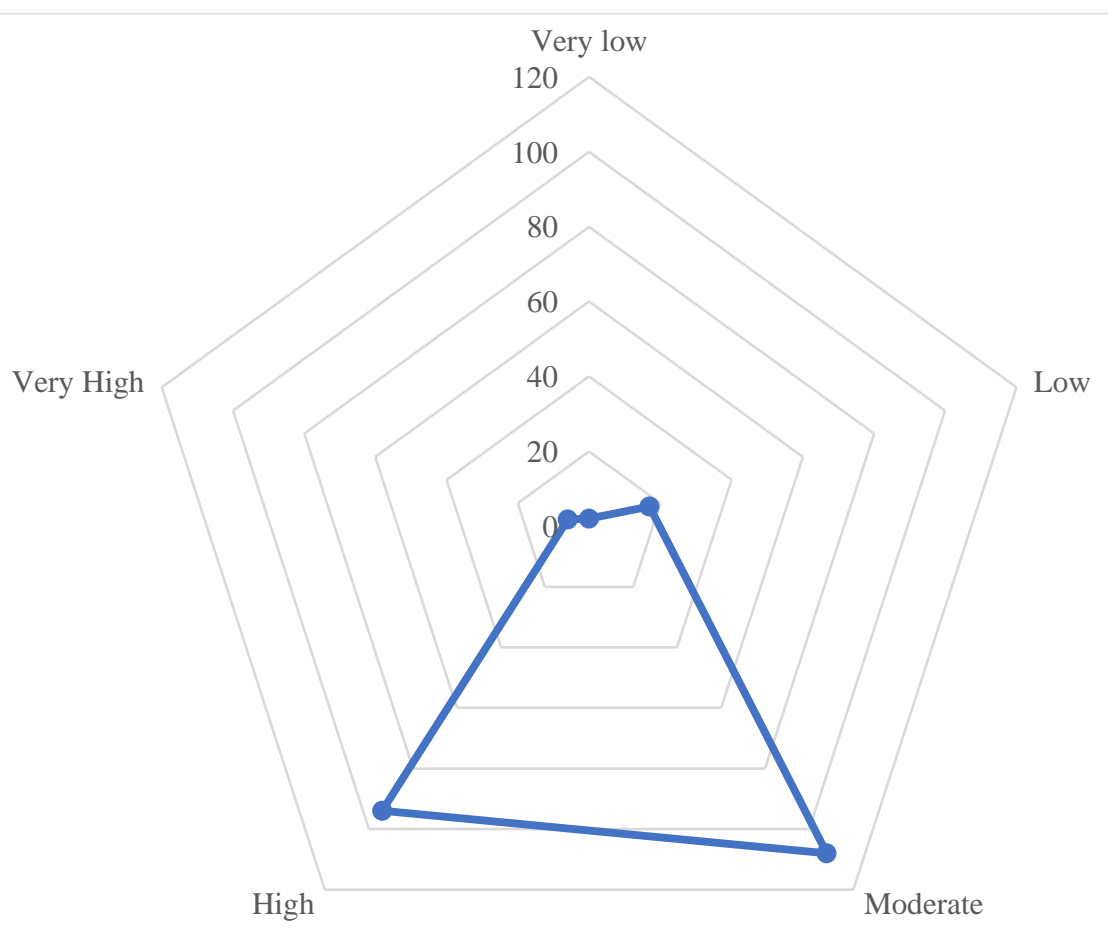


Table 2 - One Sample T-test

\begin{tabular}{|c|c|c|c|c|c|c|c|c|c|}
\hline \multicolumn{10}{|c|}{ One Sample T-test } \\
\hline \multirow[t]{3}{*}{ Code } & \multirow[t]{3}{*}{ Barriers } & \multirow[t]{3}{*}{ Mean } & \multicolumn{7}{|c|}{ Test Value $=4.0$} \\
\hline & & & \multirow[t]{2}{*}{$\mathbf{t}$} & \multirow[t]{2}{*}{ df } & \multirow{2}{*}{$\begin{array}{l}\text { Sig. (2- } \\
\text { tailed)-P- } \\
\text { value }\end{array}$} & \multirow[t]{2}{*}{$\begin{array}{c}\text { Mean } \\
\text { Difference }\end{array}$} & \multicolumn{2}{|c|}{$\begin{array}{l}\text { 95\% Confidential Interval of } \\
\text { the Difference }\end{array}$} & \multirow[t]{2}{*}{ Remarks } \\
\hline & & & & & & & Low & Upper & \\
\hline BF1 & $\begin{array}{l}\text { Adoption of different contract forms of project } \\
\text { delivery }\end{array}$ & 3.63 & -6.534 & 226 & 0.000 & -0.366 & -0.48 & -0.26 & Significant \\
\hline BF2 & The design, orientation and structure of the building & 3.76 & -4.601 & 226 & 0.000 & -0.238 & -0.34 & -0.14 & Significant \\
\hline BF3 & Planning of different construction sequences & 3.79 & -3.891 & 226 & 0.000 & -0.207 & --0.31 & -0.10 & Significant \\
\hline BF4 & Planning of different construction techniques & 3.89 & -1.921 & 226 & 0.056 & -0.106 & -0.21 & 0.00 & Not Significant \\
\hline BF5 & $\begin{array}{l}\text { Lengthy approval for new technologies within the } \\
\text { organization }\end{array}$ & 3.77 & -3.888 & 226 & 0.000 & -0.229 & -.035 & -0.11 & Significant \\
\hline BF6 & $\begin{array}{l}\text { Longer time required during the pre-construction } \\
\text { processes }\end{array}$ & 3.81 & -3.499 & 226 & 0.001 & -0.194 & -0.30 & -0.08 & Significant \\
\hline BF7 & $\begin{array}{l}\text { Difficulty in comprehending the sustainable } \\
\text { specifications in the contract details }\end{array}$ & 3.81 & -3.470 & 226 & 0.001 & -0.189 & -0.30 & -0.08 & Significant \\
\hline BF8 & $\begin{array}{l}\text { Difficulty in approving payment disbursement to } \\
\text { suppliers and subcontractors }\end{array}$ & 3.77 & -3.955 & 226 & 0.000 & -0.229 & -0.34 & -0.11 & Significant \\
\hline BF9 & $\begin{array}{l}\text { Difficulty in the selection of subcontractors in } \\
\text { providing smart sustainable construction services }\end{array}$ & 3.87 & -2.434 & 226 & 0.016 & -0.128 & -0.23 & -0.02 & Significant \\
\hline BF10 & $\begin{array}{l}\text { More time is required to implement smart } \\
\text { construction practices onsite }\end{array}$ & 3.82 & -3.301 & 226 & 0.001 & -0.181 & -0.29 & -0.07 & Significant \\
\hline BF11 & $\begin{array}{l}\text { More alteration and variation with the design } \\
\text { during the construction processes }\end{array}$ & 3.86 & -2.544 & 226 & 0.012 & -0.141 & -0.25 & -0.03 & Significant \\
\hline BF12 & $\begin{array}{l}\text { Specific budget specification of the smart } \\
\text { sustainable building project }\end{array}$ & 3.96 & -0.737 & 226 & 0.462 & -0.040 & -0.15 & 0.07 & Not Significant \\
\hline BF13 & Required date of completion & 3.77 & -4.072 & 226 & 0.000 & -0.233 & -0.35 & -0.12 & Significant \\
\hline BF14 & $\begin{array}{l}\text { Level of risk the client is willing to take in Smart } \\
\text { Building Technologies (SBTs) }\end{array}$ & 3.85 & -2.799 & 226 & 0.006 & -0.150 & -0.26 & -0.04 & Significant \\
\hline BF15 & $\begin{array}{l}\text { Special request from client pertaining to specific } \\
\text { Smart Building Technologies to be used }\end{array}$ & 3.88 & -2.118 & 226 & 0.035 & -0.119 & -0.23 & -0.01 & Significant \\
\hline
\end{tabular}




\begin{tabular}{|c|c|c|c|c|c|c|c|c|c|}
\hline BF16 & $\begin{array}{l}\text { Lack of communication and interest among project } \\
\text { team members }\end{array}$ & 3.88 & -2.357 & 226 & 0.019 & -0.123 & -0.23 & -0.02 & Significant \\
\hline BF17 & $\begin{array}{l}\text { Smart building consultant delay in provident } \\
\text { information }\end{array}$ & 3.81 & -3.499 & 226 & 0.001 & -0.194 & -0.30 & -0.08 & Significant \\
\hline BF18 & $\begin{array}{l}\text { Conflict of interest between consultant and project } \\
\text { manager }\end{array}$ & 3.75 & -4.208 & 226 & 0.000 & -0.251 & -0.37 & 0.13 & Significant \\
\hline BF19 & $\begin{array}{l}\text { High cost in smart sustainable materials and } \\
\text { equipment }\end{array}$ & 4.14 & 2.594 & 226 & 0.010 & 0.141 & 0.03 & 0.25 & Significant \\
\hline BF20 & $\begin{array}{l}\text { Availability of smart sustainable material and } \\
\text { equipment }\end{array}$ & 3.95 & -0.940 & 226 & 0.348 & -0.048 & -0.15 & 0.05 & Not Significant \\
\hline BF21 & Resistance to change from traditional practices & 3.92 & -1.596 & 226 & 0.112 & -0.079 & -0.18 & 0.02 & Not Significant \\
\hline BF22 & $\begin{array}{l}\text { Technical Difficulties during construction } \\
\text { processes or Lack of the technical skills regarding } \\
\text { smart technologies and techniques }\end{array}$ & 3.98 & -0.350 & 226 & 0.727 & -0.018 & -0.12 & 0.08 & Not Significant \\
\hline BF23 & $\begin{array}{l}\text { Unfamiliarity with Smart Building Technology } \\
\text { /Worker's unaware of the correct methods and } \\
\text { procedures }\end{array}$ & 3.99 & -0.158 & 226 & 0.875 & -0.009 & -0.12 & 0.10 & Not Significant \\
\hline BF24 & Government policy & 3.87 & -2.506 & 226 & 0.013 & -0.128 & -0.23 & -0.03 & Significant \\
\hline BF25 & Unforeseen circumstances in smart building project & 3.87 & -2.530 & 226 & 0.012 & -0.132 & -0.24 & -0.03 & Significant \\
\hline BF26 & $\begin{array}{l}\text { Structure and Organization of the Construction } \\
\text { Industry }\end{array}$ & 3.85 & -2.886 & 226 & 0.004 & -0.145 & -0.24 & -0.05 & Significant \\
\hline
\end{tabular}


Table 3 - Communalities

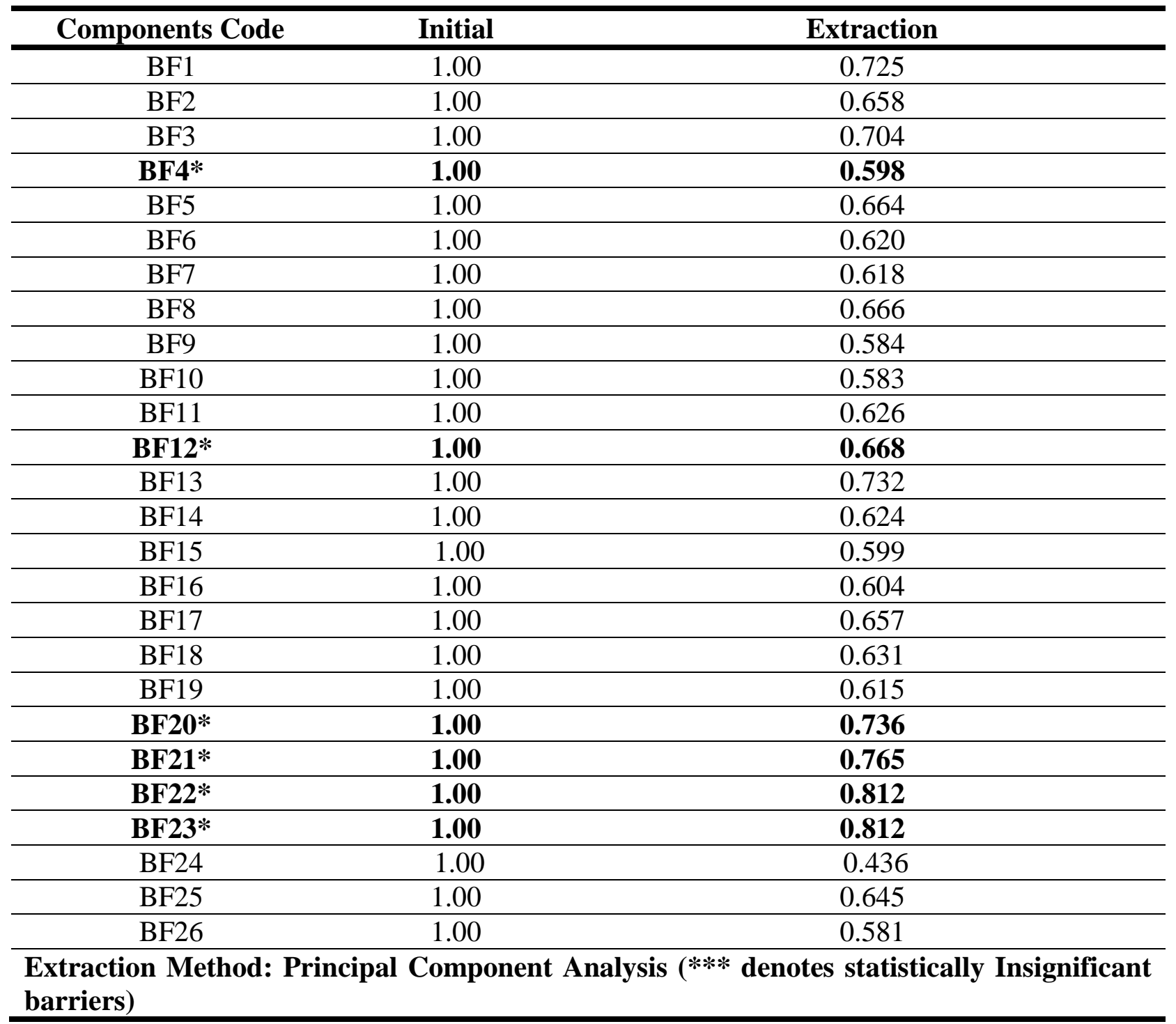


Table 4 - Total Variance Explained

Total Variance Explained

\begin{tabular}{|c|c|c|c|c|c|c|c|}
\hline \multirow[t]{2}{*}{ Components } & \multirow[t]{2}{*}{ Total } & \multicolumn{2}{|c|}{ Initial Eigenvalues } & \multicolumn{3}{|c|}{$\begin{array}{c}\text { Extraction Sums of Squared } \\
\text { Loadings }\end{array}$} & \multirow{2}{*}{$\begin{array}{c}\begin{array}{c}\text { Rotation } \\
\text { of Sums } \\
\text { of }\end{array} \\
\text { Squared } \\
\text { Loadings } \\
\text { Total }\end{array}$} \\
\hline & & $\begin{array}{c}\% \text { of } \\
\text { variance }\end{array}$ & $\begin{array}{c}\text { Cumulative } \\
\%\end{array}$ & Total & $\begin{array}{c}\% \text { of } \\
\text { Variance }\end{array}$ & $\begin{array}{c}\text { Cumulative } \\
\%\end{array}$ & \\
\hline BF1 & 13.883 & 53.395 & 53.395 & 13.883 & 53.395 & 53.395 & 11.820 \\
\hline $\mathrm{BF} 2$ & 1.808 & 6.953 & 60.348 & 1.808 & 6.953 & 60.348 & 9.664 \\
\hline BF3 & 1.274 & 4.900 & 65.247 & 1.274 & 4.900 & 65.247 & 9.243 \\
\hline BF4*** & 0.996 & 3.831 & 69.078 & & & & \\
\hline BF5 & 0.973 & 3.742 & 72.820 & & & & \\
\hline BF6 & 0.766 & 2.946 & 75.766 & & & & \\
\hline BF7 & 0.602 & 2.315 & 78.081 & & & & \\
\hline BF8 & 0.566 & 2.177 & 80.258 & & & & \\
\hline BF9 & 0.533 & 2.048 & 82.308 & & & & \\
\hline BF10 & 0.472 & 1.816 & 84.123 & & & & \\
\hline $\mathrm{BF} 11$ & 0.443 & 1.704 & 85.826 & & & & \\
\hline BF12*** & 0.415 & 1.596 & 87.422 & & & & \\
\hline BF13 & 0.390 & 1.499 & 88.921 & & & & \\
\hline BF14 & 0.363 & 1.398 & 90.318 & & & & \\
\hline BF15 & 0.327 & 1.257 & 91.575 & & & & \\
\hline BF16 & 0.289 & 1.111 & 92.686 & & & & \\
\hline BF17 & 0.257 & 0.989 & 93.675 & & & & \\
\hline BF18 & 0.255 & 0.981 & 94.657 & & & & \\
\hline BF19 & 0.237 & 0.910 & 95.567 & & & & \\
\hline BF20**** & 0.231 & 0.889 & 96.457 & & & & \\
\hline BF21*** & 0.178 & 0.686 & 97.143 & & & & \\
\hline BF22*** & 0.174 & 0.668 & 97.811 & & & & \\
\hline BF23*** & 0.160 & 0.615 & 98.426 & & & & \\
\hline BF24 & 0.155 & 0.594 & 99.020 & & & & \\
\hline BF25 & 0.140 & 0.537 & 99.557 & & & & \\
\hline BF26 & 0.115 & 0.443 & 100.000 & & & & \\
\hline
\end{tabular}


Table 5 - Rotated Component Matrix

\begin{tabular}{|c|c|c|c|}
\hline \multirow[t]{2}{*}{ Variables } & \multicolumn{3}{|c|}{ Components } \\
\hline & 1 & 2 & 3 \\
\hline BF13 & 0.731 & & \\
\hline BF12*** & 0.725 & & \\
\hline BF11 & 0.691 & & \\
\hline $\mathrm{BF} 25$ & 0.684 & & \\
\hline BF17 & 0.677 & & \\
\hline BF18 & 0.652 & & \\
\hline BF26 & 0.627 & & \\
\hline BF8 & 0.625 & & \\
\hline $\mathrm{BF} 15$ & 0.600 & & \\
\hline BF16 & 0.550 & & \\
\hline BF14 & 0.512 & & \\
\hline BF10 & 0.490 & & \\
\hline BF1 & & 0.799 & \\
\hline $\mathrm{BF} 2$ & & 0.767 & \\
\hline BF5 & & 0.747 & \\
\hline $\mathrm{BF} 3$ & & 0.740 & \\
\hline BF4*** & & 0.658 & \\
\hline BF6 & & 0.627 & \\
\hline BF7 & & 0.551 & \\
\hline BF9 & & 0.543 & \\
\hline BF23*** & & & 0.828 \\
\hline BF22*** & & & 0.809 \\
\hline BF20**** & & & 0.778 \\
\hline BF21*** & & & 0.754 \\
\hline BF19 & & & 0.713 \\
\hline BF24 & & & 0.412 \\
\hline
\end{tabular}

Extraction Method: Principal Component Analysis.

Rotation Method: Varimax with Kaiser Normalization

a. Rotation converged in 7 iteration

(*** denotes statistically Insignificant barriers) 
Figure 2 - Scree Plot

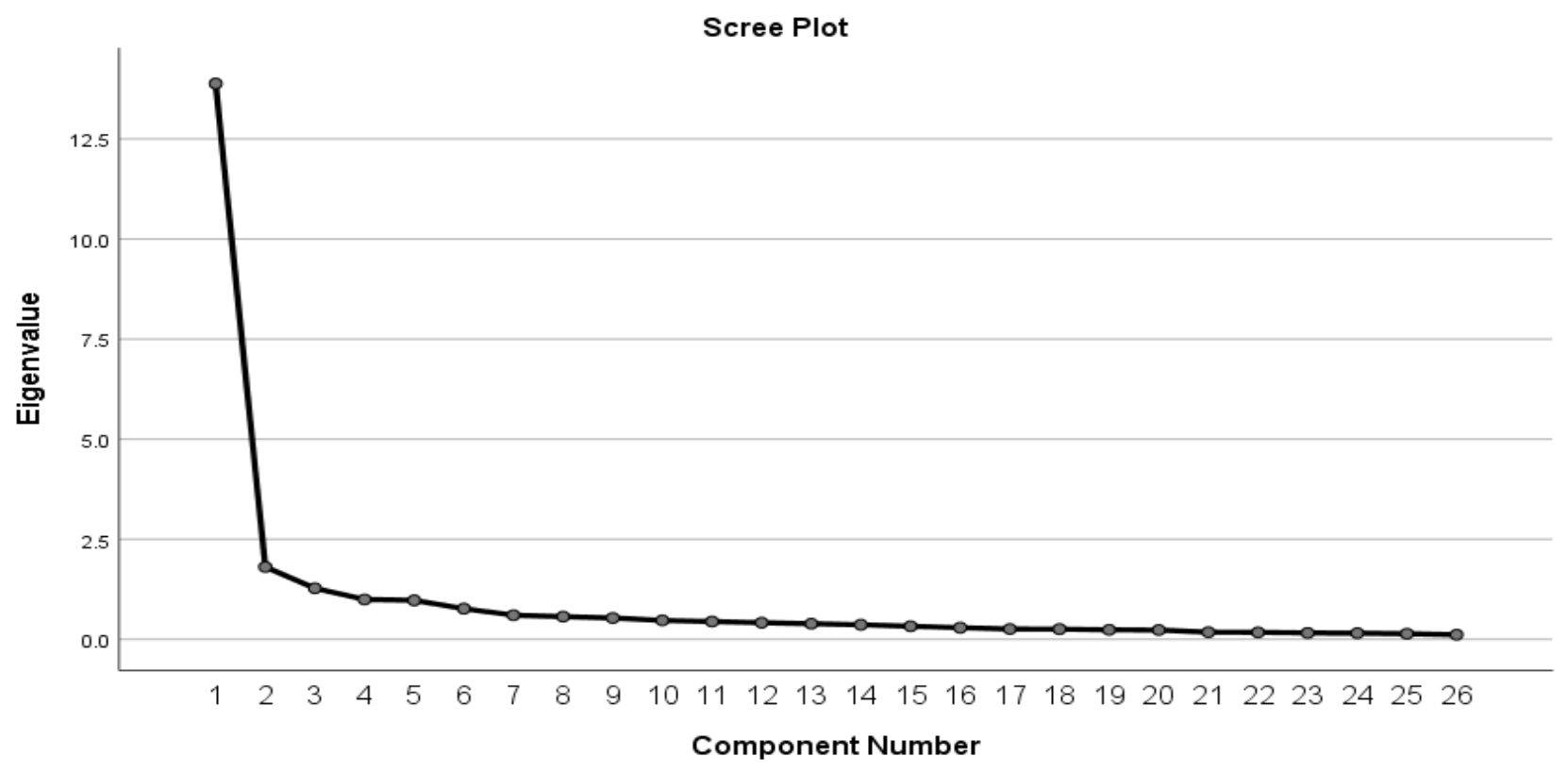


Table 6 - Components and Their Variables

\begin{tabular}{|c|c|c|c|}
\hline Code & Barriers & $\begin{array}{l}\text { Factor } \\
\text { Loading }\end{array}$ & $\begin{array}{l}\text { \% Variance } \\
\text { Explained }\end{array}$ \\
\hline & Components One: Structure and Time-Related Barriers & & $\mathbf{5 3 . 3 9 5}$ \\
\hline BF13 & Required date of completion & 0.731 & \\
\hline BF12*** & Specific budget specification of the smart sustainable building project & 0.725 & \\
\hline BF11 & More alteration and variation with the design during the construction processes & 0.691 & \\
\hline $\mathrm{BF} 25$ & Unforeseen circumstances in smart building project & 0.684 & \\
\hline BF17 & Smart building consultant delay in provident information & 0.677 & \\
\hline BF18 & Conflict of interest between consultant and project manager & 0.652 & \\
\hline BF26 & Structure and Organization of the Construction Industry & 0.627 & \\
\hline BF8 & Difficulty in approving payment disbursement to suppliers and subcontractors & 0.625 & \\
\hline BF15 & $\begin{array}{l}\text { Special request from client pertaining to specific Smart Building Technologies to be } \\
\text { used }\end{array}$ & 0.600 & \\
\hline BF16 & Lack of communication and interest among project team members & 0.550 & \\
\hline BF14 & Level of risk the client is willing to take in Smart Building Technologies (SBTs) & 0.512 & \\
\hline BF10 & More time is required to implement smart construction practices onsite & 0.490 & \\
\hline & Component Two: Construction-Related Barriers & & 6.953 \\
\hline BF1 & Adoption of different contract forms of project delivery & 0.799 & \\
\hline BF2 & The design, orientation and structure of the building & 0.767 & \\
\hline BF5 & Lengthy approval for new technologies within the organization & 0.747 & \\
\hline BF3 & Planning of different construction sequences & 0.740 & \\
\hline BF4*** & Planning of different construction techniques & 0.658 & \\
\hline BF6 & Longer time required during the pre-construction processes & 0.627 & \\
\hline BF7 & Difficulty in comprehending the sustainable specifications in the contract details & 0.551 & \\
\hline BF9 & $\begin{array}{l}\text { Difficulty in the selection of subcontractors in providing smart sustainable } \\
\text { construction services }\end{array}$ & 0.543 & \\
\hline & Component Three: Human, Policy and Cost-Related Barriers & & 4.900 \\
\hline BF23*** & $\begin{array}{l}\text { Unfamiliarity with Smart Building Technology /Worker's unaware of the } \\
\text { correct methods and procedures }\end{array}$ & 0.828 & \\
\hline $\mathbf{B F 2 2} * * *$ & $\begin{array}{l}\text { Technical Difficulties during construction processes or Lack of the technical } \\
\text { skills regarding smart technologies and techniques }\end{array}$ & 0.809 & \\
\hline BF20*** & Availability of smart sustainable material and equipment & 0.778 & \\
\hline BF21*** & Resistance to change from traditional practices & $\mathbf{0 . 7 5 4}$ & \\
\hline BF19 & High cost in smart sustainable materials and equipment & 0.713 & \\
\hline $\mathrm{BF} 24$ & Government policy & 0.412 & \\
\hline
\end{tabular}

(*** denotes statistically Insignificant barriers) 